\title{
The Virtual Tempest, Digital Caliban and Robotic Ariel in the Trans- Created Toufann: A Mauritian Fantasy by Dev Virahsawmy
}

\section{Mustabshira Siddiqui}

\begin{abstract}
Shakespeare has always been the source of inspiration to the generations all over the world stage. Toufann by Dev Virahsawmy is one such piece of clone. The world has taken a drastic turn in the $21^{\text {st }}$ century. Digitalisation is the only normal in abnormality of the millennials with the upsurge of 'technology' as the 'spear' of Shakespeare and 'network' a 'villain' as Prospero creating 'magic' and 'illusion' in our lives. 'Virtual' has become 'real' and real has taken a backseat in the heaven called 'home'.

In this techno-savvy, digital, virtual world; it is imperative for the 'Humanities' to adapt the new normal. Toufann is one such child of this techno-renaissance playwright Dev Virahsawmy, a Mauritian playwright creating a 'tempest' by virtual slides on computer.Caliban is no more looked as black, beast, filthy or low born; he is a smart, handsome, creative, technical man with a heart already lost to Cupid's bow. Miranda is a feminist; reading Simone de Beauvoir's The Second Sex pregnant with Kalibann's child. Ariel is a Robot; now emotionless, mechanical and artificial. Ferdinand is infertile, fickle minded and wants the companionship of Robot Ariel. The present paper will discuss the techno aspect of the play in detail with the tinge of focus on the turns of events in the neomillennials.
\end{abstract}

Keywords: Techno-renaissance, Digital characters, Virtual actions.

\section{Introduction}

In this age of clinical trials and masked faces one cannot imagine a play by Shakespeare on the stage without technology. Hence Dev Virahsawmy has forthrightly written Toufann: A Mauritian Fantasy in the $21^{\text {st }}$ century pre Covid-19 crisis. We live in the pre Covid-19 and present disastrous world where as homo-sapiens everywhere is trying to create a productive world amidst the natural disasters taking us by storm all over the globe. Having said that I would like to give emphasis to the new normal which is the virtual world; we are taking refuge in the virtual reality from our real physical world. Toufann is one such play which gives a sigh of relief to the Shakespearean spirit with its technology and virtual reality. Since Shakespeare forgave his enemies at the end of The Tempest by creating a magical tempest in the sea; here is the $21^{\text {st }}$ century Toufann created by Mauritian human in a Mauritian setting three centuries later with technology.

\section{Mauritian Literature and Digitalization}

Mauritius, a subtropical island nation situated in the Indian Ocean, "an ex-French and British colony (1721-1810 and 1810-1968 respectively), independent since 1968 and proclaimed a Republic in 1992, is a multi-ethnic and multilingual island"(Mooneram, 1999, p. 17). Up till 
its independence, most of the Mauritian Literature was;"heavily dominated by English and French, the militant post-independence climate raised the awareness that Creole could be the means of a cultural and political liberation"(Mooneram, 1999, p.17). Major themes in Mauritian Literature include racial and social issues, post modernism and post colonialism.Due to the brilliant works of Mauritian dramatists like Dev Virahsawmy, Creole has emerged as a means of literary creation despite the prejudice against it. The switch to Creole was caused by the desire to establish theatre as a vehicle for national culture, and authors like Virahsawmy, believed that only Creole can truly express and present the Mauritian experiences and voice.He used theatre as a means to present the ongoing digitalization of Mauritius. For instance, he sets Toufann in a technically advanced era where robots are also present.

\section{Adaptations of The Tempest}

"The context of Shakespeare's words is constantly shifting and if it cannot adapt, either through interpretation or adaptation, the words will be lost to literary history" (Talbot, 2019, p.6). Due to the universal themes and relatable characters ofShakespeare's play The Tempest, it is being constantly adapted whether in the form of other plays, novels, opera, songs, and movies. Talbot cites the character of Caliban as the main reason behind the endless adaption and recreation of the afore mentioned play:

The Tempest survives in part because while the character of Caliban can be interpreted as a bigoted caricature of a slave, in recent years the play has been reimagined as a post-colonial condemnation of slavery and colonization, meeting the morals of our day. (Talbo, 2019, p. 6)

Margret Atwood's novel Hag-Seed, which is one of the most well-knownadaptations of The Tempest, modifies the character of Caliban. The title alludes to Prospero's derogatory term for Caliban, who is the son of a witch named Sycorax. In the book, a group of prisoners who perform The Tempest reimagine Caliban's ending (Talbot, 2019, p.6). Aimé Césaire's A Tempest is one of the earliest adaptations The Tempest. It aptly "conveys his anti-colonist ideas, exploring the relationship between Prospero, the colonizer, and his colonial subjects, Caliban and Ariel, from the perspective of the colonized." (Abd-Aun, Diab,2016, p. 54)

Adaptations of The Tempestare not limited to literary texts."That the marriage between Shakespeare and Hollywood has produced some offbeat, fascinating, strange, and sometimes simply funny offspring is not a secret" (Caroti, 2004, p. 2). The earliest movie based on Shakespeare's The Tempest can be traced back to a silent film in 1905. The Yellow Sky (1958), Forbidden Planet (1956) andThe Tempest (1979) are some well-known movies based on the Tempest. The film Forbidden Planet presented the story line of the Tempest with a scientific tint. Julie Taymor's 2010 movie The Tempest revolutionized the plot of the tempest bychallenging the;

Stereotypical character identities in Shakespeare's plays through casting, dialogue, and editing. Casting Helen Mirren as Prospera changes the dominant figure from a patriarchal tyrant to a matriarchal enlightened despot while casting Djimon Hounsou as Caliban forces an examination of colonial history in Shakespeare. (Vinson, 2014, p. 4)

\section{Dev Virahsawmy as a Mauritian Playwright}

"Dev Virahsawmy is the first post-colonial Mauritian playwright to use Creole as dramatic expression and remains the figurehead of the theatre in Creole" (Mooneram, 1999, p. 17). He advocated that Creole should be the medium of expression in literary, political as well as colloquial contexts. "From 1966 to 1987, he was actively involved in Mauritian politics, being one of the founders of the Mouvement Militant Mauricien. $L i$, Virahsawmy's first play in Mauritian Creole, was written in 1972" (Sandten, 2016, p. 40). Dev Virahsawmy was a passionate campaigner of the Mauritian Creole (his preferred term was "Morisien"), he published many of his Shakespeare adaptations in Mauritian Creole; ZenaralMakbess (A 


\section{The Virtual Tempest, Digital Caliban and Robotic Ariel in the Trans-Created Toufann: $A$ Mauritian Fantasy by Dev Virahsawmy}

translation of Macbeth, 1997), Enn ta Senn Dan Vid (a translation of Much Ado About Nothing, 1995) Zil Sezar (a translation of Julius Ceasar, 1987), and Toufann (an adaptation of The Tempest, Hamlet, King Lear and Othello, 1991). His Creole play Sir Toby was written in reciprocation to Border Crossings' production of Twelfth Night in Mauritius.In Toufann, instead of merely translating The Tempest, he:

Uses Shakespeare's themes, his language and his characters as a trigger for social commentary and critical reflection on the political, cultural and economic realities of Mauritian everyday life, as well as universal concerns that affect communities around the globe in postcolonial societies and beyond. (Sandten, 2016, p. 54)

"Virahsawmy's writing of translations and adaptations of Shakespeare puts him alongside a range of other writers from the African continent who have found in Shakespeare a vehicle to represent and redress postcolonial concerns and issues" (Sandten, 2016, p. 40). He has tried to master a Shakespearean play without any baggage of racist past and cruel tragedies. He has no anxiety as a non-European and no complex on being called a postcolonial writer. That is why we don't find any 'writing back to the empire' lines in Toufann which has been a tradition by almost every writer since the inception of postcolonial writings. The traditional lines "this island's mine, by Sycorax my mother?" (Act I, Scene II, Shakespeare. 1988, p. 18), conclude: "you taught me language; and my profit on't. Is I know how to curse" (Act I, Scene II, Shakespeare, 1988, p. 19). Having said that it is imperative to discuss Dev Virahsawmyeven has to be translated into English by Nisha and Michael Walling to reach to the Global audience. One cannot escape the notion of translation even Ngugi wrote Decolonizing the Mind in English to make the colonised understand the intricacies and efficacies of the English Language. Though as Raja Rao aptly says in his foreword to Kanthapura "it is very difficult to write in an alien tongue"(1938); one loses the actual essence and also one is unable to find perfect words for some traditions hence we see this in Toufann when Virahsawmy's translated play couldn't compensate the word "Mari sa" (Bravo) (Ak I, SENN V, Virahsawmy, 1993, p. 10) in the alien tongue. By writing in Creole, Virahsawmy has proven that language can be used to express one's cultural identity and to raise voice against the injustices of political institutions as it is more difficult to suppress:

The subversive presence of a popular tongue that the political establishment cannot control. When Shakespeare is translated from English to Creole, the audience also changes from an elite minority to a general majority as Creole is the lingua franca of Mauritius and a vehicle for the continuation of the oral tradition among its people. (Sandton, 2016, p. 49)

Very much like Shakespeare, Virahswami also uses humour as a form of social commentary. In the play Toufann when Poloniouss says: "I was using metaphor, Your Majesty," Edmon, unable to understand him, rudely answers: "I don't care what you were using metal for - I want a better speech at the Royal Wedding!" (Virahswami, 2001, p. 241)

\section{Toufann: A MauritianFantasy}

"Toufann is a Hindustani and Bhojpuri word for cyclone; a familiar natural occurrence in Mauritius... the title starts an intertextual argument that situates the play within a specific history and society" (Mooneram, 1999, p. 18). Toufann has been translated into English by Nisha and Michael Walling. The play's original title was 'Ennfanteziantrwaak,' which means "a fantasy in three acts."Toufann is a well knitted play in three acts and a revenge plot as its soul driving force leading to many complex events including comic scenes by Kaspalto and Dammaro. One never forgets to quote Ben Jonson for Shakespeare "he was not for an age but for all times' (Hinman,1996)." Unlike so many adaptations of Shakespeare Toufannis not only a postcolonial adaptation, it's an effort to recreate, rewrite the play in an independent atmosphere of $21^{\text {st }}$ century times which gives the sense of 'transcreation' to the play. Dev Virahsawmy wrote this play in his native tongue 'Mauritian Creole' to give it a sense of 
'belongingness' to his own soil.

The Tempest is completely appropriated in an alien tongue (Mauritian Creole) from the native tongue (British). But it carries the essence of Shakespeare like an 'objective corelative'. The sense of human relations, politics of power, love and betrayal are very much evident parts of this play. An island conquered and a throne lost is still the weaving thread of this play.The process of reconciliation and forgiveness is still the potent plot of Toufann irrespective of the technology and digitalization. Love still conquers over hate and manipulation.

\section{Toufann as a Techno Play; a Transcreation}

Dev Virahsawmy has materialized the Asian dream of technology and digitalization in this play very aptly by creating a techno play. With all the characters having a command over their specialties; Kalibann an apprentice in the lab of Computer expert Prospero; Kordelia having a command over feminism as a student of feminist studies reading Simone de Beauvoir and asserting her ideas in real life.Toufann has magically exchanged white magic into technology. Since $21^{\text {st }}$ century is no more the traditional age of saints and snake charmers anymore. Dev Virahsawmy has converted the Shakespearean idea of $16^{\text {th }}$ century white magic into digital magic of the present age where one can easily revolutionize the entire world just by the click of buttons. He gives power to the technology and tries to convey a message to the world stage to upgrade their plays in the coming age. The perfect example of this digital magic is the product of the technology 'Aryel'; who is no more an airy spirit now; it has become a Robot with all the powers of a robot machine. But the robot technology comes with its pros and cons; we see at the end of the play how Robot Aryel behaves weirdly and malfunctions; which also clearly indicates the realism in the writings of Dev Virahsawmy. Technology can never replace the real beings is the indication in this techno play through the character of Aryel. As we see the robot was programmed by Prospero to function according to his creator but the robot gets infected by the virus of cupid and falls in love with Ferjinan; the prince of Naples supposed to be married to Kordelia according the Master Mind Computer Expert Prospero. But his all plans fall apart at the final moment of the play. Here one can see the tinge of postcolonial mindset of Dev Virahsawmy. At the end of the play Prospero's plans fall apart and he (as the center of all the events) can not hold his empire island together.

Hence Toufann can be called a perfect postcolonial techno play in every sense of its characters. The characters have been trans-created in the $21^{\text {st }}$ century atmosphere and launched as the potent hand grenades on the world stage at border crossings in London (1991). It was translated in the one and only global language of the Britishers or Shakespeare.In a nutshell the plot of Toufann: A Mauritian Fantasy goes like this; Prospero, the powerful philosopher king, spends his time writing and carrying out research in his laboratory. He leaves his brother Yago, the Prime Minister with the responsibility of running the country's affairs. Yago is the borrowed cunning character from Othello. Prospero relates to his daughter Kordelia (borrowed from King Lear) how Yago got into power, which resembles the old Yago of Othello who tried to get into power with deception but loses, in the $21^{\text {st }}$ century Toufannhe succeeds in his deception:

Hard-working, intelligent...too intelligent.

Cunning. Little by little, he managed to get absolute power for himself. Without me even noticing, he gets rid of ministers one after the other-putting in his men everywhere, police, army, the law...everywhere you go, nothing but his men. And so, bit by bit, he got all the power. It's meant to be basic to any democracy that you separate the executive from the legislature! Not him...(Virahsawmy, 1999, p. 220)

Kalibann is no more a beast, black and filthy being. He is a handsome, modern computer apprentice in the technical lab of Prospero. He can marry Prospero's daughter now 
with her affirmation in the marriage. She is now Kordelia; assertive daughter with complete loyalty towards her father and husband at the same time which reflects the Kordelia of King Lear."The reappropriation of Kalibann is designed to debunk the prejudices against 'halfcastes', and to overthrow the slave-master relationship that has, in various ways and under different forms, been part of the history of Mauritius." (Mooneram, 1999, p. 20)

In Toufann, Kordelia is shown reading Simone de Beauvoir'sThe Second Sex, which reflects; the feminist revolution has already taken place and women are no more Shakespeare's Mirandas. They won't be controlled by the magic of their father to fall in love with the right person. Kordelia is pregnant with Kalibann's child and also asserts to marry him by her famous statement when Prospero shows defiance for this proposal. She famously replies "it is enough for me that he has human blood." (Act III, Scene I, Virahsawmy, 1999)

Aryel is a robot without any sexual orientation but surprisingly he falls in love with Ferjinan. Their $21^{\text {st }}$ century names are Aryel and Ferjinan as could be fitted in Mauritian Creole. Since Toufann was first published in Mauritian Creole not in English language, it is another assertation on the part of the playwright of $21^{\text {st }}$ century. English is no more a language of the playwrights for Shakespearean adaptations or recreations.

'Trinculo and Stephana become 'Kaspalto' and 'Dammarro', stereotypical Mauritian names connoting a drunkard and a drug addict respectively, who discover abundant whiskyfilled coconuts and marijuana fields on the island" (Mooneeram, 1999, p. 18). Toufann is a transcreation of The Tempest in every aspect. The play begins with the virtual slide 'Toufann' in the sea for Prospero's enemies. Kalibann is assisting Prospero in the computer lab to create big visual slides in simulation of tempest. Kalibann is constantly texting Kordelia about the developments in the lab and visual slides. She is annoyed with her father for giving such a task to Kalibann on a weekend. She wanted to spend the weekend evening with him. But Prospero asked him to stay and help him in this last project after this project Kalibann will no longer need his apprenticeship and is free to open his own lab. Hence Kalibann is giving his best shot in the last project because after being free he will ask Kordelia's hand from his guide, which looks favorable to both of them. Aryel is helping both of them by taking commands in his circuits in the brain machine. In this process he meets Ferjinan; the prince of Naples. Ferjinan is an infertile male with emotions for the trans-sexual beings. Robot Aryal and Impotent Ferjinan fall in love by first glance amidst all chaos of virtual Toufann in the sea. "The cultural productions that stem from the 'unexpected transfers' across time and space, across languages and cultures, bring about an island bubbling with dynamic recreation, and endless possibilities" (Mooneeram, 1999, p. 18). Change and replacement of old by new is an important theme in Toufann; Just as Virahsawmy's Prospero cannot cling to the ways of an old continuous tradition, and must accept the process of change and renewal, so Toufann, incorporating Shakespeare and Mauritian Creole, traditional and modern popular theatres, becomes a perpetual movement of searching, creation and recreation, of boundary crossings, in terms of content as well as form. (Moorenam, 1999, pp. 20-21)

\section{Conclusion}

Prospero is aghast at the end of the play when he discovers Kordelia is carrying the child of Kalibann and interested to marry him. Another shock takes him by surprise when he discovers Ferjinan and Robot Aryel are in love on which he remarks; "There is a virus in Robot Aryal's system because I did not programme him to have emotions" (Act III, Virahsawmy, 1999). This is the final nail in the coffin by Dev Virahsawmy in the play as a Trans-creation of The Tempest.Kordelia and Kalibann become the new king and the Queen for the post-colonial, technical and digital generation. Kalibann is no more a Mulatto apprentice of Prospero; rather he is the King in charge to rule the democratic republic of Mauritius with impartial and just behavior as being a commoner himself. Prospero is left surprised to explore more ways to forgive his own daughter like King Lear, apprentice 
Kalibann like postcolonial generations and Robot Aryel for falling in love with the wrong person at the wrong time. This entire idea deconstructs the Elizabethan dramas of Shakespeare with a fresh breath of air.Toufann does not merely provide an insight into yet another post-colonial rewriting of Shakespeare, but gives a glimpse of the dynamic possibilities of literary and cultural productions of Mauritius through its Creole literary voice. (Mooneeram, 1999, p. 21)

Hence, it's a Techno Mauritian play in true sense of its characters and plot with the language politics and digitalization as the topping of the plot. There are some minor characters as well as Kaspalto and Dammaro as their names suggests the localization of language. One also sees how Kaspalto and Dammarodance in the Mauritian islands on a local Bhojpuri tune. There is Polonius also as the counselor of the King Prospero. As we know Polonius was famous for his loyalty in Hamlet.All the minor and major characters make this play Toufann a wonderful recreation of The Tempest in particular and other Shakespearean plays in general with the fittest of the characters deconstructing their roles well.

\section{References}

Ashcroft, B., Griffith, G., \& Tiffin, H. (1989). The Empire Writes Back. Routledge.

Abd-Aun, R.K., \& Qaiser M. D. (2016). Adaptation and Appropriation in Aimé Césaire's a Tempest. European Journal of Language and Literature Studies, Volume 2(2), p. 54.

Benham, M., Osofisan, F. \& Gibbs, J. (2001). African Theatre Playwrights and Politics. James Curry.

Caroti, S. (n.d.). Science Fiction, Forbidden Planet, and Shakespeare's The Tempest. https://doi.org/10.7771/1481-4374.1214

Hinman, C. (Ed) (1996). The First Folio of Shakespeare. $2^{\text {nd }}$ ed. Introduction by Blayney, P. W.M., W. W. Norton.

Caroti, S. (2004). Science Fiction, Forbidden Planet, and Shakespeare's The Tempest. https://doi.org/10.7771/1481-4374.1214

Hinman, C. (Ed) (1996). The First Folio of Shakespeare. $2^{\text {nd }}$ ed. Introduction by Blayney, P. W.M., W. W. Norton.

Mooneeram, R. (1999). Prospera's Island Revisited: Dev Virahsawmy's Toufann (In memory of my beloved mother, Nirmal Virahsawmy Mooneeram).

https://ro.uow.edu.au/kunapipi/vol21/iss1/7

Rao, R. (2014). Author's Foreword in Kanthapura. Penguin Books.

Rao, R. (2014). Author's Foreword in Kanthapura. Penguin Books.

Sandten, C. (2016). Transcultural Tempests: Dev Virahsawmy's Toufann, A Mauritian

Fantasy. Postcolonial Interventions, 1(2), pp. 40, 49, 54.

Shakespeare, W.(1988). The Tempest. Yale University Press.

Talbot, H. (2019). Folklore-In-the-Making: Analyzing Shakespeare's The Tempest and Adaptations as Folklore. All Student Publications. 257. p. 6.

https://scholarsarchive.byu.edu/studentpub/257

Thiong'o, N. W. (1986). Decolonizing the Mind: The Politics of Language in English Literature. James Curry.

Virahsawmy, D. (2001). Toufann: A Mauritian Fantasy. (Walling, N. \& Walling. M., Trans.) In Benham, M., Osofisan, F. \& Gibbs, J.( Ed.), African Theatre - Playwrights \& 
Politics. James Currey Press, p. 241.

Virahsawmy, D. (1993). Toufann: ENN FANTEZI AN 3 AK. Boukie Banane, p.10.

Virahsawmy, D. (1999). Toufann: A Mauritian Fantasy. (Walling, N. \& Walling, Trans.). Border Crossings.

Vinson, A. W. (2014). Challenging identity hierarchies in Julie Taymor's Tempest. College of Liberal Arts \& Social Sciences Theses and Dissertations, 161, p.4, https://via.library.depaul.edu/etd/161

\section{Bio-note}

Dr Mustabshira Siddiqui is an Assistant Professor in the Department of English, Taibah University, Saudi Arabia. The thrust area of her Doctoral research is British Drama in the wake of rewritings and adaptations of Shakespearean plays camouflaging with postcolonialism and African theatre.Her specialization is in Postcolonialism, Feminism, Shakespearean Dramas and their adaptations.She has written more than thirty-five research papers until now on various topics related to her specialized areas and published her articles in various national and international journals of repute. She also runs a blog about Mental and Emotional Health. She has been awarded the certificate of appreciation by the department of English language and literature for her hard work and dedication at Taibah University, Saudi Arabia. Recently she has won the Global Teacher AKS EducationAward 2020 India. She is also an oxford learner in the department of continuing education, University of Oxford, UK.

Email: mustab.siddiqui@gmail.com 